DEIfGA IATA

Jurnal Ilmu Hukum

FAKULTAS HUKUM UMSU

\title{
KONSEP TANGGUNG JAWAB SERTA PERANAN NEGARA TERHADAP KESEJAHTERAAN RAKYAT (Persepektif Hukum Internasional dan Ekonomi Islam)
}

\author{
Halimatul Maryani, Adawiyah Nasution \\ Universitas Muslim Nusantara UMN Al-Washliyah \\ Jl. Sisingamangaraja Medan-Sumatera Utara \\ Email: maryaniritonga@yahoo.co.id
}

\begin{abstract}
Abstrak
Negara adalah suatu organisasi yang memiliki wilayah, berkumpulnya orang, lembaga pemerintahan dan pengakuan rakyat kepada negara yang bertujuan untuk mewujudkan keadilan, memberikan kepastian hukum, memberikan ketertiban dan keamanan bagi rakyat (rakyat). Penulisan ini menggunakan metode penelitian hukum yuridis normatif (penelitian normatif. Spesifikasi penelitian dalam penulisan ini adalah penelitian deskriptif analitis. Tujuannya adalah untuk memberikan gambaran, mempelajari, menjelaskan dan menganalisis. Masalah dalam penelitian ini adalah bagaimana konsep tanggung jawab dan peran negara terhadap perspektif kesejahteraan rakyat dari hukum internasional dan ekonomi Islam. Pandangan Islam tentang institusi atau institusi negara tidak dapat dipisahkan dari konsep kolektif terpadu yang ada dalam landasan moral dan ketentuan syariah Islam, misalnya konsep persaudaraan (ukhuwah), pencerahan (tausiah), kepemimpinan (khilafah) adalah dasar untuk pengembangan lembaga-lembaga Islam dalam bentuk Negara, artinya agama adalah dasar atau prinsip sebagai kepercayaan dalam hubungan monoteisme dengan Kekuatan sebagai Pencipta (khaliq).
\end{abstract}

Kata Kunci: Peran, Negara, Kesejahteraan, Rakyat

\section{Abstract}

State is an organization that has territory, a gathering of people, government institutions and people's recognition to the state which aims to realize justice, provide legal certainty, provide order and security for the people (the people). This writing uses the normative juridical legal research method (normative research. The specification of the research in this paper is analytical descriptive research. The aim is to provide an overview, study, explain and analyze. The problem in this research is how the concept of responsibility and the role of the state towards the perspective of people's welfare from international law and Islamic economics, the Islamic view of state institutions or institutions cannot be separated from the integrated collective concept contained in the moral foundation and Islamic sharia provisions, for example the concept of brotherhood (ukhuwah), enlightenment (tausiah), leadership (khilafah) is the basis for the development of Islamic institutions in the form of the State, meaning religion is the basis or principle as a belief in the relationship of monotheism with Strength as the Creator (khaliq).

Keywords: Role, State, Welfare, People

\section{PENDAHULUAN}

Negara adalah suatu organisasi yang terbesar (akbar) yang terdiri dari tiga unsur yaitu adanya wilayah, adanya rakyat, dan adanya pemerintah, di mana dalam suatu negara juga terdapat 'hukum' yang berfungsi dan bertujuan untuk mewujudkan keadilan yang hakiki, memberikan kepastian hukum, memberikan ketertiban serta keamanan bagi masyarakat (rakyat). Organisasi itu suatu pertambahan jabatan-jabatan atau lapangan-lapangan kerja (M. Solly Lubis, 1990, h. 1). Secara universal dalam materi ilmu negara J.G Starke juga mengemukakan pendapatnya tentang pengertian negara yaitu bahwa suatu negara adalah satu 


\section{DE IFGA LATA}

Jurnal Ilmu Hukum

FAKULTAS HUKUM UMSU
Konsep Tanggung.Jawab...(Halimahtul, Adawiyah)

Volume 3 Nomor 1, Januari-Juni 2018, 29-38

DOI: $\underline{\text { https://doi.org/10.30596/dll.v3i1.3147 }}$

sistem yang mengatur hubungan-hubungan yang ditetapkan oleh dan diantara manusia sendiri, sebagai suatu alat untuk mencapai tujuan-tujuan dan yang paling penting diantaranya adalah satu sistem yang menaungi manusia dalam melakukan kegiatan-kegiatannya (Mohd. Sanwani Nasutian, 35).

Brierly menyatakan bahwa mengenai keberadaan suatu negara adalah:

A new state comes in toexistensi, when a community acquires no momentarily, but whit a reasonable probability of permanence, the essentials characteristically of a state, namely an organized government, a defined territory, and such a degree of indefendence of control by any other state as to capable of conducting its own internasional relations" (S. Tasrif, 1987, h. 10).

Ketiga unsur ini saja belum cukup untuk mengembangkan suatu negara itu, maka dilengkapi dengan unsur yang keempat yakni pengakuan Negara secara internasional dan merupakan subjek utama dari hukum internasional, baik ditinjau secara historis mapun secara faktual (de facto and de yure). Peranan negara sebagai subjek hukum internasional lama kelamaan juga semakin dominan, oleh karena bagian terbesar dari hubungan-hubungan internasional yang dapat melahirkan prinsip-prinsip dan kaidah-kaidah hukum internasional yang telah dilakukan oleh negara. Bahkan hukum internasional itu sendiri boleh dikatakan bagian terbesar terdiri dari hubungan hukum antara negara dengan negara lainnya.

Sebagai subjek hukum internasional dalam arti klasik, negara yang berdaulat penuh adalah negara yang tidak lagi tergantung pada negara lain. Anggapan semacam ini masih ada pengaruhnya hingga saat ini, dimana masih terdapat anggapan bahwa hukum internasional itu pada hakikatnya adalah hukum antar negara. Dalam arti yang modern, tidak hanya terbatas pada negara yang berdaulat penuh yang merupakan subjek hukum internasional, tetapi juga negara-negara bagian seperti Bellorusia dan Ukraina semasa keberadaan Uni Sovyet.

Kelebihan negara sebagai subjek hukum internasional dibandingkan dengan subjek hukum internasional lainnya adalah bahwa negara memiliki apa yang disebut dengan kedaulatn (sovereignty). Kedaulatan diartikan sebagai kekuasaan yang tertinggi, pada awal mulanya diartikan sebagai suatu kebulatan dan keutuhan yang tidak dapat dipecah-pecah dan dibagi-bagi serta tidak dapat ditempatkan di bawah kekuasaan lain. Akan tetapi kini arti dan makna kedaulatan tersebut telah mengalami perubahan. Kedaulatan tidak lagi dapat dipandang sebagai sesuatu yang bulat dan utuh, melainkan dalam batas-batas tertentu sudah tunduk pada pembatasan-pembatasan. Maka dengan demikian pembatasan tersebut tidak lain adalah hukum internasional dan kedaulatan dari sesama negara lainnya. Suatu negara yang berdaulat, tetap tunduk pada hukum internasional atau dengan kata lain tidak boleh melanggar ketentuan dan merugikan kedaulatan negara lain.

Lalu bagaimana tanggung jawab dan peranan Negara untuk memajukan ekonomi serta kesejahteraan rakyat? Dalam Pasal 33 Undang-Undang Dasar Negara Republik Indonesia Tahun 1945 dinyatakan bahwa:

Perekonomian disusun sebagai usaha bersama berdasarkan atas asas kekeluargaan (Ayat

1) dan perekonomian nasional diselenggarakan berdasar atas demograsi ekonomi dengan prinsip kebersamaan, efisiensi berkeadilan, berkelanjutan, berwawasan lingkungan, kemandirian, serta dengan menjaga keseimbangan kemajuan dan kesatuan ekonomi nasional (Ayat 3).

Islam juga memiliki konsep Negara, tata dan sistem pemerintahan serta kesejahteraan ekonomi yang komprehensif. Pandangan islam terhadap lemabaga atau institusi Negara tidak terlepas dari konsep kolektif terpadu yang ada dalam landasan moral dan ketentuan syariah islam, misalnya konsep persaudaraan (ukhuwah), pencerahan (tausiah), kepemimpinan (khalifah) adalah merupakan landasan pembangunan institusi islam (ketatalembagaan) yang 
Jurnal Ilmu Hukum

FAKULTAS HUKUM UMSU
Konsep Tanggung.Jawab...(Halimahtul, Adawiyah)

Volume 3 Nomor 1, Januari-Juni 2018, 29-38

DOI: $\underline{\text { https://doi.org/10.30596/dll.v3i1.3147 }}$

berbentuk Negara, artinya agama adalah pondasi atau asas sebagai keyakinan hubungan ketauhidan kepada Sang Kuasa sebagai Sang Pencipta (khaliq), sementara kekuasaan dalam konsep negara adalah negara, sehingga antara keduanya ada hubungan yang saling menguatkan. artinya agama menjadi pondasi bagi penguasa Negara untuk berbuat kepada rakyat menuju kesejahteraan dan kemakmuran rakyatnya. Sementara suatu Negara itu adalah menjadi alat bagi agama agar tersebar luas dan terlaksana secara benar.

Berdasarkan latar belakang tersebut di atas, maka adapun yang menjadi perumusan masalah yang diangkat dalam tulisan ini adalah bagaimanakah konsep tanggung jawab serta peranan negara terhadap kesejahteraan rakyat persepektif hukum internasional dan ekonomi islam.

\section{METODE PENELITIAN}

Penulisan ini menggunakan metode penelitian hukum yuridis normatif (normatif research), yaitu penelitian hukum yang dilakukan dengan cara meneliti bahan pustaka atau data skunder (Seokanto dan Sri Muji, 2003, h. 15). Spesifikasi penelitian dalam penulisan ini berupa penelitian deskriptif analistis. Deskriptif adalah menunjukan komparasi atau hubungan seperangkat data dengan seperangkat data yang lain, dan maksudnya adalah untuk memberikan gambaran, menelaah, menjelaskan dan menganalisis (Soekanto, 1996, h. 63).

Sesuai jenis dan sifat penelitiannya, maka sumber data yang digunakan dalam penulisan ini adalah data skunder yang terdiri dari bahan hukum primer berupa; Aturan hukum yang terkait konsep tanggung jawab serta peranan negara terhadap kesejahteraan rakyat persepektif hukum internasional dan ekonomi islam. Bahan hukum sekunder terdiri dari buku-buku, jurnal ilmiah, makalah dan artikel ilmiah yang dapat memberi penjelasan tentang bahan hukum primer. Bahan hukum tersier; berupa Kamus Besar Bahasa Indonesia (KBBI) dan lain sebagainya dalam menemukan defenisi dari istilah-istilah dalam membahas tentang konsep tanggung jawab serta peranan negara terhadap kesejahteraan rakyat persepektif hukum internasional dan ekonomi islam.

Prosedur yang digunakan untuk mengumpulkan data dalam penilitian ini berupa dokumentasi yaitu pedoman yang digunakan berupa catatan atau kutipan, penelusuran literatur hukum, buku-buku dan lainnya yang bertalian dengan identifikasi masalah dalam penilitian ini dengan cara offline maupun online. Analisa bahan hukum dilakukan dengan menggunakan metode analisa konten (centent analysis method) yang dilakukan dengan menguraikan materi peristiwa hukum atau produk hukum secara rinci guna memudahkan interpretasi dalam pembahasan (Marzuki, 201, h. 171).

\section{PEMBAHASAN}

\section{Tanggung Jawab Serta Peranan Negara Persepektif Hukum Internasional}

\section{Konsep Negara}

Munculnya suatu negara sebenarnya sudah ada sejak beberapa abad sebelum Masehi serta dikaji dalam Ilmu Negara. Para pemikir Yunani seperti Sacrates, Plato dan Aristoteles telah mengajarkan teori tentang bagaimana proses terjadinya negara. Akan tetapi pengertian dan makna negara pada saat itu tidak sama dengan pengertian dan makna negara yang berkembang pada saat sekarang ini, karena makna negara saat itu hanya meliputi lingkungan kecil atau negara kota saja yang disebut dengan 'polis'.

Istilah negara merupakan terjemahan dari bahasa Asing seperti dari bahasa Belanda dan Jerman yaitu 'staat', dalam Bahasa Inggris 'state', kemudian Bahasa Perancis 'etat'. Katakata Asing tersebut dialihkan dari kata bahasa Latin yaitu 'status atau statum'. Sebelum abad ke-15 dipergunakan kata 'civitas' atau 'res publica' terutama oleh orang-orang Romawi. Selanjutnya pada abad ke-5 dipegunakan kata 'Lo Stato' dari bahasa Italia yang dipakai dalam laporan-laporan wakil persekutuan Italia. Menurut pada ahli, Machiavelli adalah orang yang 


\section{DE IFGA LATA}

Jurnal Ilmu Hukum

FAKULTAS HUKUM UMSU
Konsep Tanggung.Jawab...(Halimahtul, Adawiyah)

Volume 3 Nomor 1, Januari-Juni 2018, 29-38

DOI: $\underline{\text { https://doi.org/10.30596/dll.v3i1.3147 }}$

pertama memperkenalkan istilah Lo Stato tersebut dalam kepustakaan ilmu politik. Namun demikia menurut Kranenbrug istilah Lo Stato itu merupakan istilah yang telah tepat untuk menunjukkan negara territorial yang muncul dalam abad ke-17 sebagai istilah yang menunjukkan fungsi dan segenap organ umum yang tersusun rapi mendiami suatu wilayah tertentu (Rahmad A. dan M. Halimi, 1994, h. 9).

Uraian tersebut menunjukkan bahwa istilah negara mengalami perkembangan yang cukup panjang, dan selanjutnya menimbulkan sebuah pertanyaan, apa yang dimaksud dengan negara? Untuk menjawab pertanyaan tersebut, ternyata para ahli mengemukakan pandangan yang berbeda-beda mengenai pengertian negara. Adanya perbedaan pandangan tersebut disebabkan para ahli tersebut memandang dan menitik beratkan perhatian tentang negara tentang aspek yang berbeda-beda pula, misalnya Hegel memandang negara sebagai organisasi kesusilaan, Logemann memandang negara sebagai organisasi kekuasaan, R.M. Mac Iver memandang negara sebagai organisasi politik. Selain itu juga G. Jellinek yang dianggap sebagai Bapak Ilmu Negara itu dengan dua aspek yaitu aspek sosial dan aspek yuridis. Kemudian Hans Kelsen memandang negara itu dari satu aspek saja yaitu aspek hukum. Oppenheimer meninjau negara sebagai konsep sosiologis, bahkan Nawiasky meninjau negara sebagai idea, kenyataan sosial, dan sebagai pengertian hokum (Rahmad A. dan M. Halimi, 1994, h. 10).

Namun demikian sebagai rujukan untuk memahami pengertian dan makna Negara, dapat dilihat pandangan para sarjana seperti, Aristotels menyatakan negara (polis) adalah persekutuan dari kelurga dan desa guna memperoleh hidup yang sebaik-baiknya. Hans kelsen misalnya menyatakan negara adalah suatu susunan pergaulan hidup bersama dengan tata paksa. Seiring dengan itu Max Weber juga menyatakan bahwa negara adalah suatu masyarakat yang mempunyai monopoli dalam menggunakan kekerasan fisik secara sah dalam suatu wilayah. Tak kalah pentingnya Hugo Gratius juga menyatakan negara adalah suatu persekutuan yang sempurna dari orang-orang yang merdeka untuk memperoleh perlindungan hukum.

Maka dengan demikian pada hematnya negara adalah suatu organisasi kekuasaan yang berdaulat yang dengan tata pemerintahan melaksanakan tata tertib atas suatu umat di suatu daerah tertentu. Bagaimana bentuk dan coraknya negara selalu merupakan organisasi kekuasaan. Maka organisasi kekuasaan itu selalu mempunyai tata pemerintahan, dan tata pemerintahan ini selalu melaksanakan tata tertib masyarakat di daerah tertentu.

\section{1) Unsur-Unsur Negara}

Secara umum suatu negara harus mempunyai unsur yang sangat penting yaitu yang terdiri dari wilayah,rakyat, dan pemerintah. Maka ketiga unsur ini disebut sebagai unsure konstitutif. Namun untuk ketiga unsur tersebut harus juga ditunjang dengan unsur lain yaitu adanya pengakuan (negara) dunia internasional. Termasuk konstitusi dan negara yang berdaulat. Ini disebut sebagai unsur deklaratif. Untuk lebih jelasnya dalam memahami unsurunsur dalam negara ini, berikut akan dijelaskan masing-masing antara lain:

a) Adanya Wilayah

b) Adanya Rakyat

c) Adanya Pemerintah

d) Ada Pengakuan negara lain (recognition)

\section{Fungsi Negara}

Pada umumnya fungsi dan tujuan negara saling berkaitan serta mempunyai hubungan timbale balik dan tidak dapat dipisahkan antara fungsi dan tujuan negara tersebut. Tujuan negara menunjukkan suatu cita-cita atau harapan yang hendak dicapai oleh suatu negara, sedangkan fungsi negara adalah merupakan pelaksanaan cita-cita dalam kenyataan.

Idiologi yang dianut suatu negara akan banyak mempengaruhi fungsi yang harus 


\section{DE IFGA LATA}

Jurnal Ilmu Hukum

FAKULTAS HUKUM UMSU
Konsep Tanggung.Jawab...(Halimahtul, Adawiyah)

Volume 3 Nomor 1, Januari-Juni 2018, 29-38

DOI: $\underline{\text { https://doi.org/10.30596/dll.v3i1.3147 }}$

dilaksanakan oleh negara tersebut. Oleh karena itu lahirlah beberapa teori tentang fungsi negara, seperti teori individualism, sosialisme, komunisme, anarkhisme dan berikut akan diuraikan:

Teori Individualisme, dalam teori ini dinyatakan bahwa fungsi negara adalah sebagai pemelihara dan penjaga ketertiban serta keaamanan individu dan masyarakat. Negara tidak perlu turut campur tangan dalam urusan di luar hal-hal yang berkaitan dengan ketertiban dan keamanan, artinya negara bersifat pasif, dan baru aktif atau bertindak apabila ada pelanggaran terhadap keamanan dan ketertiban individu serta masyarakat. Maka fungsi Negara dalam hal ini adalah disebut sebagai 'Penjaga Malam'.

Teori Sosialisme, menyatakan bahwa fungsi negara bukan hanya sebagai pemelihara ketertiban dan keamanan (penjaga malam), akan tetapi harus diperluas sedemikian rupa sehingga tiada lagi aktivitas sosial yang tidak diselenggarakan oleh negara. Semua aktivitas negara ditujukan kepada pemenuhan kesejahteraan bersama.

Teori komunisme, menyatakan bahwa fungsi negara adalah sebagai alat pemeksa oleh kelas pemilik alat produksi terhadap kelas lainnya sebagai upaya untuk mempertahankan alat produksi yang dimilikinya.

Teori anarkhisme menyatakan bahwa fungsi negara adalah $\mathrm{An}=$ tidak, arcchein $=$ pemerintah, artinya anarhis adalah 'tidak ada pemerintah atau tanpa pemerintah'. Maka fungsi negara dan pemerintah dapat pula dilaksanakan oleh kelompok atau perhimpunan yang dibentuk dengan cara suka rela, tanpa alat-alat paksaan, tanpa polisi, tanpa hukum dan tanpa pengadilan.

\section{Tujuan Negara}

Setiap negara pasti mempunyai tujuan yang hendak dicapai. Rumusan tujuan negara merupakan salah satu hal yang sangat penting dalam suatu negara, karena kajian tentang tujuan negara akan berkaitan dengan bentuk negara, pembentukan badan-badan negara, fungsi dan tugas-tugas badan-badan tersebut, serta hubungan antara organ yang satu dengan organ yang lainnya. Tujuan negara diperlukan untuk mengarahkan segala kegiatan negara dan sebagai pedoman dalam penyusunan alat perlengkapan negara dan organ atau badan pemerintah. Dengan demikian tujuan negara yang dikemukan oleh para ahli dengan rumusan yang berbeda-beda seperti:

Tujuan negara menurut Shang Yang adalah, mengumpulkan kekuasaan negara yang sebesar-besarnya, tujuan ini hanya dapat terwujud atau dapat dicapai dengan cara menyiapkan tentera yang kuat, berdisiplin, serta bersedia menghadapi segala kemungkinan dan dalam negara terdapat dua pihak yang saling berhadapan yaitu pemerintah dan negara.

Tujuan negara menurut Nicola Machiavelli, adalah untuk menghimpun dan memperbesar kekuasaan negara agar mencapai kebesaran, kehormatan dan kesejahteraan bangsa Italia. Maka seorang raja harus tampil cerdik, seperti kancil, ganas, keras, berani seperti seekor singa.

Tujuan negara menurut Dante Allighieri, adalah untuk menciptakan perdamaian dunia. Dante berpendapat bahwa perdamaian dan kebahagian di duniatidak akan tercapai selama masaa ada raja-raja yang mempunyai kekuasaan sendiri-sendiri.

Tujuan negara menurut Immanuel Kant, adalah membentuk dan memlihara hak dan kemerdekaan warga negara. Dalam upaya memelihara hak dan kemerdekaan warga negara, maka perlu dibentuk hukum yang dirumuskan dalam perundang-undangan. Perundangundangan tersebut bukan merupakan kehendak perorangan atau penguasa saja, akan tetapi merupakan kehendak seluruh warga negara secara universal.

Tujuan negara menurut Kaun Sosialis, adalah membrikan kebahagian yang sebesarbesarnya dan merata bagi setiap manusia. Berkaitan dengan tujuan negara tersebut, tujuan negara Indonesia pada umumnya dapat diketahui dari Undang-Undang Dasar 1945 (UUD 1945) atau konstitusi. Hal ini didasarkan pada alenia ke-4 Pembukaan UUD 1945, bahwa 
DEIFGA LATA

Jurnal Ilmu Hukum

FAKULTAS HUKUM UMSU
Konsep Tanggung.Jawab...(Halimahtul, Adawiyah)

Volume 3 Nomor 1, Januari-Juni 2018, 29-38 DOI: $\underline{\text { https://doi.org/10.30596/dll.v3i1.3147 }}$

tujuan Negara Republik Indonesia adalah:

a) Melindungi segenap bangsa Indonesia dan seluruh tumpah darah Indonesia

b) Memajukan kesejahteraan umum

c) Mencerdaskan kehidupan bangsa

d) Ikut melaksanakan ketertiban dunia, berdasarkan kemerdekaan, perdamaian abadi, dan keadilan sosial; dan semuanya berdasarkan Pancasila.

\section{Aspek Hukum Internasional Menegenai Tanggung Jawab Negara}

J.G. Starke menyatakan bahwa peraturan hukum internasional tentang tanggung jawab negara yang menyangkut keadaan sekitar, di mana dan prinsi-prinsip dengan mana negara yang dirugikan untuk mendapatkan hak yang dideritanya. Tanggung jawab negara adalah dinyatakan sebacara teoritatif untuk dibatasi hanya pada tanggung jawab negara untuk tindakan-tindakan salah secara hukum internasional.

Rabecca juga mengatakan bahwa tanggung jawab negara dalam hukum internasional merujuk kepada pertanggung jawaban yaitu satu negara terhadap negara lainnya akan ketidaktaatannya memenuhi kewajiban yang ditentukan oleh sistem hukum internasional. Suatu negara dapat meminta petanggung jawaban bagi kerugian kepada negara tergugat itu sendiri. Maka dengan demikian tanggung jawab suatu negara itu adalah sebagai segala sesuatu yang berkenaan dengan penentuan tentang atas dasar apa dan pada situasi yang bagaimana suatu negara dapat dianggap telah melakukan kesalahan atau tindakan yang salah secara internasional.

Waupun sampai saat ini, mengenai konsep 'tanggung jawab negara' belum jelas dan belaum tegas, dengan kata lain belum ada ketentuan-ketentuan hukum yang jelas tentang tanggung jawab negara ini, meskipun kekurangan-kekurangan itu tidak mengurangi pentingnya prinsip tanggung jawab negara sebagai salah satu prinsip yang fundamental dalam hukum internasional.

MN. Shaw mengemukakan beberapa karakteristik yang menunjukkan timbulnya tanggung jawab negara, yaitu :

1) Adanya suatu kewajiban hukum internasional yang berlaku antara dua negara tertentu,

2) Adanya suatu perbuatan atau kelalaian yang melanggar kewajiban hukum internasional tersebut, yang melahirkan tanggung jawab negara.

3) Adanya kerusakan atau kerugian sebagai akibat adanya tindakan yang melanggar hukum atau kelalaian.

Jadi dengan demikian jelasnya, tanggung jawab negara akan timbul manakala :

1) Adanya pelanggaran atas suatu kewajiban berdasarkan hukum internasional, oleh suatu negara,

2) Pelanggaran tersebut menimbulkan kerugian atau kerusakan terhadap negara lain,

3) Adanya hubungan antara pelanggaran dan kerugian itu yang menyebabkan negara yang melakukan pelanggaran harus mempertanggung jawabkannya.

\section{Macam-Macam Tanggung Jawab Negara}

Secara umum ada dua macam tanggung jawab terhadap suatu negara antara lain adalah :

1) Delictual liability,

maksudnya tanggung jawab perbuatan melawan hukum, di mana tanggung jawab perbuatan melawan hukum ini lahir dari setiap kesalahan atau kelalaian sustu negara terhadap orang Asing dalam wilayahnya, atau dalam wilayah lain. Hal ini dapat timbul karena :

a) Eksplorasi ruang angkasa

Misalnya negara peluncur satelit selalu bertanggung jawab terhadap setiap kerugian yang disebabkan oleh satelit kepada benda-benda (objek) di wilayah negara lain. sistem 


\section{DE IFGA LATA}

Jurnal Ilmu Hukum

FAKULTAS HUKUM UMSU
Konsep Tanggung.Jawab...(Halimahtul, Adawiyah)

Volume 3 Nomor 1, Januari-Juni 2018, 29-38 DOI: $\underline{\text { https://doi.org/10.30596/dll.v3i1.3147 }}$

tanggung jawab seperti ini adalah tanggung jawab absolute.

b) Eksplorasi nuklir

Negara-negara yang bertanggung jawab setiap kerusakan yang disebabkan karena kegiatankegiatan dalam bidang eksplorasi nuklir, dimana sistem pertanggung jawabannya juga adalah sistem absolut, tidak penting apakah sebelumnya negara tersebut telah melakukan tindakan-tindakan pencegahan, tetapi kerugian tetap terjadi.

c) Kegiatan-kegiatan lintas batas nasional

Pada hakikatnya setiap negara harus mengawasi dan mengatur setiap kegiatan-kegiatan di dalam wilayahnya, baik yang sifatnya public maupun perdata. Jiak kemudian kegiatankegiatan ini melewati batas-batas negara dan mengakibatkan kerugian terhadap negara lain, maka negara yang wilayahnya dipakai itu harus bertanggung jawab.

2) Tanggung Jawab Atas Pelanggaran Perjanjian

a) Pelanggaran suatu perjanjian

Tidak bisa dielakkan, kemungkinan besar suatu negara dapat saja melanggar suatu perjanjian yang telah dibuat dengan negara lain (peserta), yang mengakibatkan keruggian terhadap negara lainnya. Maka dengan demikian pelanggaran suatu perjanjian tersebut akan menimbulkan suatu kewajiban yaitu membayar ganti rugi. Seberap banyak ganti rugi yang akan dikeluarkan untuk pelanggaran tersebut, ini dapat ditentukan oleh Mahkamah Internasional, Pengadilan, Peradilan Arbitrase melalui perundingan.

b) Pelanggaran kontrak

Suatu negara dapat melakukan kontrak dengan orang, pihak asing atau pengusaha asing (swasta) untuk berbagai tujuan dan pelanggaran tersebut bisa saja akan terjadi terhadap suatu pihak atau pejabat. Biasanya pejabat negara yang terlibat dalam kontrak tersebut melakukan suatu pelanggaran, dalam hukum internasional dikenal tindakan ultra vires, yaitu suatu tindakan-tindakan pejabat negara yang melebihi kapasitasnya dan bisanya terjadi dalam hukum perjanjian. Maka dalam hal ini negara tetap dapat diminta diminta pertanggung jawabannya, meskipun pejabat tersebut melaksanakan tugas melebihi kapasitas atau batas wewenang yang diberikan oleh negara kepadanya.

\section{Pengecualian Tanggung Jawab Negara}

Bicara tentang tanggung jawab, maka segala yang diperbuat dalam hal melanggar kewajiban-kewajiban atau yang dapat merugikan pihak lain, maka itu hatus dipertanggung jawabkan oleh yang melanggar tersebut. Tetapi dalam keadaan darurat masih ada pengecualian-pengecualian untuk tidak bertanggung jawab, yaitu keadaan yang dimaksud adalah:

1) Tindakan tersebut dilakukan dengan persetujuan negara yang dirugikan

2) Penerapansanksi-sanksi yang sah

3) Force majeure

4) Tindakan yang sangat diperlukan

5) Tindakan bela diri.

\section{Tanggung Jawab Untuk Pelanggaran Internasional}

Di dalam parakteknya, kebanyakan kasus tanggung jawab paling tidak dihadapan pengadilan internasional, timbul dari kesalahan-kesalahan yang diduga telah dilakukan oleh negara-negara yang bersangkutan. Yang dimaksud dengan kesalahan dalam hal ini adalah pelanggaran suatu kewajiban oleh suatu negara berdasarkan hukum internasional dan yang bukan merupakan pelanggaran suatu kewajiban yang berdasarkan kontrak semata-mata, di mana kesalahan-kesalahan seperti ini disebut dengan istilah pelanggaran internasional. 


\section{DE IFGA LATA}

Jurnal Ilmu Hukum

FAKULTAS HUKUM UMSU
Konsep Tanggung.Jawab...(Halimahtul, Adawiyah)

Volume 3 Nomor 1, Januari-Juni 2018, 29-38

DOI: $\underline{\text { https://doi.org/10.30596/dll.v3i1.3147 }}$

Kebanyakan kasus yang berkaitan dengan tanggung jawab negera ini berkenaan dengan kerugian yang diderita warga negara di luar negeri. Tentunya sebagian besar hukum tentang masalah kerugian misalnya berkenaan dengan perlindungan warga negara di luar negeri. Kerugian ini juga bermacam-macam jenisnya, seperti kerugian terhadap harta benda dalam kerusuhan, kerugian pribadi, penangkapan yang tidak pantas oleh penguasa setempat, penolakan pengadilan setempat untuk memberi pengadilan atau ganti rugi yang seharusnya, dan lainnya. Contoh, adalah kewajiban pada negara untuk memberikan ganti rugi yang pantas atau kerugian yang diderita dan kewajiban untuk melindungi warga negara asing dari kerugian pribadi yang tidak pada tempatnya oleh para pejabat atau rakyatnya.

Di dalam pelanggaran internasional ini perlu digunakan pengertian 'imputabilitas' yaitu hal yang dapat dipertalikan. Hal ini dapat membantu dan menjelaskan masalah itu dalam memberikan suatu kerangka yang tepat untuk teorinya. Sebagai sebuah contoh yang praktis, jika suatu perwakilan negara $\mathrm{X}$ yang telah menyebabkan kerugian kepada seorang warga dari negara $\mathrm{Y}$ atas kerugian yang dibuat tersebut. Artinya organ atau pejabat negara $\mathrm{X}$ telah melakukan suatu kesalahan dan prilaku dalam pelanggran hukum internasional itu diperlikan (imputet) dari organ atau pejabat ke negara itu. Jadi pertalian itu adalah aakibat operasi intelektual yang diperluakan untuk menjembati jurang antara pelanggaran oleh organ atau pejabat itu dan pertanggung jawaban kepada negara itu.

Oleh karena itu imputabilitas tergantung pada pemenuhan dua kondisi:

1) prilaku suatu organ atau pejabat negara dalam pelanggaran suatu kewajiban yang ditetapkan dalam suatu peraturan hukum internasional.

2) Bahwa menurut hukum internasional, pelanggaran itu akan dipertalikan kepada negara itu. Hanya jika pelanggaran itu dapat dipertalikan maka negara itu menjadi tanggung jawab secara internasional kepada pelanggaran tersebut. Tanggaung jawab mulai di mana imputabilitas berakhir, seperti telah ditekankan oleh Komisi Hukum Internasional. (J.G starke, 1984, h. 286) "Perhubungan suatu tindakan atau kelalaian kepada seseorang oknum hukum internasional adalah suatu operasi yang kepentingannya berada dalam jangkauan hukum internasional. Dengan demikian hal ini berbeda dari eperasi sejajar yang mungkin berlangsung (tetapi tidak mesti) di bawah hukum internasional”.

\section{Peranan Negara (Pemerintah) Terhadap Kesejahteraan Rakyat Dalam Konsep Ekonomi Islam}

Tanggung jawab serta peranan Negara (pemerintah) untuk mensejahterakan rakyatnya, islam salah satunya menentukan fungsi pokok Negara dan pemerintah dalam bidang ekonomi, perdagangan (bisnis) dengan menghapuskan kesulitan ekonomi yang dialami oleh rakyat dan memberi kemudahan pada akses pengembangan ekonomi serta kesejahteraan sosial pada seluruh lapisan masyarakat.

Alqur'an menjelaskan dalam Surah Thaha ayat 118 dan 119), "bahwa sesungguhnya kamu tidak akan kelaparan di dalamnya dan tidak akan telanjang, dan sesungguhnya juga tidak akan merasa haus (dahaga) dan tidak pula akan ditimpa panas matahari di dalamnya ".

Sehubungan dengan hal tersebut, iman Al-Ghazali menguraikan tanggung jawab sosial ekonomi Negara merupakan suatu tanggung jawab penguasa adalah membantu rakyat ketika mereka menghadapi kelangkaan pangan, kelaparan dan penderitaan, khususnya ketika terjadi kekeringan (kemarau) atau ketika harga tinggi sampai rakyat mendapat penghasilan kembali, karena dalam keadaan tersebut sulit bagi mereka untuk memenuhi dua tujuan tersebut. Dalam kondisi dan situasi seperti ini Negara (pemerintah) berperan dan bertanggung jawab untuk memberi makanan kepada rakyat dan bantuan keuangan kepada mereka yang mendapat kesulitan dari kekayaan Negara supaya mereka dapat meningkatkan pendapatan mereka (Adi warman A. Karim, 2004). 


\section{DE IFGA LATA}

Jurnal Ilmu Hukum

FAKULTAS HUKUM UMSU
Konsep Tanggung.Jawab...(Halimahtul, Adawiyah)

Volume 3 Nomor 1, Januari-Juni 2018, 29-38

DOI: $\underline{\text { https://doi.org/10.30596/dll.v3i1.3147 }}$

Maka letak dan prinsip pertanggung jawaban dalam pandangan islam adalah setiap kebijakan atau tindakan apapun dan sekecil apapun akan diminta pertanggung jawabannya di hadapan Allah SWT, begitu juga setiap pertanggung jawaban publik harus pula dipertanggung jawabkan kepada publik/khayak ramai karena menyangkut kekuasaan dan wewenang serta penggunaan asset yang diamanahkan kepada pengambil kebijakan tersebut yaitu pemerintah dan negara, misalnya yang menyangkut tanggung jawab negara/pemerintah dalam bidang ekonomi adalah terciptanya lingkungan yang kondusif bagi kegiatan ekonomi, pemungutan pendapatan dari sumber-sumber yang tersedia dan menaikkan pendapatan dengan menetapkan pajak baru bila situasi memungkinkan dan penggunaan keuangan Negara untuk tujuan-tujuan yang menjadi kewajiban Negara.

Selanjutnya peranan pemerintah dalam pembangunan ekonomi dalam mensejahterakan rakyatnya tidak terlepas dari sikap dan langkah-langkah kebijakan yang harus dilakukan secara islami oleh pemerintah dan bangsa Indonesia terlebih pada masyarakat atau bangsa Indonesia yang mengetahui sistem pelaksanaan pembangunan ekonomi nasional secara islami, dengan kata lain memahami dan melaksanakan sistem ekonomi syariah dalam membangun perekonomian di Indonesia, sehingga kita akan melakukan tiga langkah strategis secara bersama-sama antara para ulama, tokoh dan para pakar ilmuan juga seluruh lapisan masyarakat sebagai realisasi dari kongres ummat islam, yaitu pengembangan ilmu ekonomi syariah, pengembangan sistem ekonomi dalam bentuk regulasi dan peraturan serta pengembangan ekonomi ummat.

Di dalam pengembangan ekonomi ummat ini, tentunya memberikan kesejahteraan kepada masyarakat, masyarakat dituntut hidup mapan, minimal untuk memenuhui kebutuhan primer, artinya terhindar hari kemiskinan. Islam memandang bahwa kemiskinan sepenuhnya adalah masalah struktural, karena Allah sebagai Sang Pencipta telah menjamin rezeki setiap makhluk yang telah, sedang dan akan diciptakannya (Zainuddin Ali, 2008, h. 33) dengan kata lain Allah menentukan rezeki tiap-tiap makhluk. Hal ini jelas ditegaskan dalam Al-Qur'an Surah Al-Ankabut (ayat 60) "Dan berapa banyak binatang yang tidak (dapat) membawa (mengurus) rezekinya sendiri, Allah-lah yang memberi rezeki kepadanya dan kepadamu dan Dia maha mendengar dan mengetahui". Dalam ayat 62 dijelaskan bahwa "Allah melapangkan rezeki bagi siapa yang dikehendaki-Nya diantara hamba-hamba-Nya dan Dia (pula) yang menyempitkan baginya. Sesungguhnya Allah Maha Mengetahui segala sesuatu".

Selanjutnya dalam surah Ar-Rum Ayat 40 dijelaskan bahwa "Allah-lah yang menciptakan kamu, kemudian memberimu rezeki, kemudian mematikanmu, kemudian menghidupkanmu (kembali). Adakah diantara yang kamu sekutukan dengan Allah itu yang dapat membuat sesuatu yang dari demikian itu ? Maha Sucilah Dia dan Maha Tinggi dari apa yang mereka persekutukan".

Di surah lain juga dijelaskan, tepatnya terdapat dalam surah Huud Ayat 6 " Bahwa tidak ada suatu binatang melata pun di muka bumi malainkan Allah-lah yang memberi rezekinya, dan Dia mengetahui tempat berdiam binatang itu dan tempat penyimpanannya. Semuanya tertulis dalam kitab yang nyata (Lauhul Mahfuzh)".

Bahwa ayat tersebut, dapat dipahami bahwa setiap makhluk yang diciptkan oleh Allah Swt, Allah telah menjamin dan memberi rezekinya. Akan tetapi dalam hal ini, tidak hanya menerima apa adanya saja, pasrah dengan berpangku tangan berusaha untuk meningkatkan kesejahteraan hidup dalam kehidupan manusia itu sendiri. Maka islam telah menutup peluang bagi kemiskinan kultural dengan memberi kewajiban mencari nafkah bagi setiap individu seperti yang telah dijelaskan dalam Al-Qur'an surah Al-Mulk Ayat 15 "Bahwa Dia-lah yang menjadikan bumi ini mudah bagi kamu, maka berjalanlah di segala penjuru dan makanlah sebahagian dari rezeki-Nya. Dan hanya kepada-Nyalah kamu kembali setelah dibangkitkan”.

Menganlisis dari ayat tersebut, maka Negara Indonesia jika dilihat dari pertumbuhan dan perkembangan penduduk yang mendiami Negara tercinta Republik Indonesia semakin 


\section{DE IFGA LATA}

Jurnal Ilmu Hukum

FAKULTAS HUKUM UMSU
Konsep Tanggung.Jawab...(Halimahtul, Adawiyah)

Volume 3 Nomor 1, Januari-Juni 2018, 29-38 DOI: $\underline{\text { https://doi.org/10.30596/dll.v3i1.3147 }}$

hari semakin bertambah, dan juga tidak menutup kemungkinan jumlah rakyat miskinpun akan bertambah bahkan sampai kepada yang sangat memperhatinkan terjauh dari kesejahteraan, dengan arti kata tanggung jawab Negara/pemerintah juga akan semakin berat. Bagaimana solusi untuk mengeva,uasi kegagalan pemerintah dan Negara dalam melakukan transformasi ekonomi secara cepat yang dapt mengurangi jumlah kemiskinan khususnya di tanah air. Dengan demikian pemerintah sebagai penguasa dalam mengambil kebijakan secara islam harus kembali kepada konsep-konsep Al-Qur'an dan prinsip-prinsip ajaran islan untuk mengembangkan pertumbuhan dan pembangunan ekonomi untuk mensejahterakan rakyat.

Selain itu juga perlu memahami bagaimana proses kepemimpinan rasulullah ketika menyebarkan islam dan meraih kesuksesan dalam berdagang untuk memajukan islam. Umar Bin Abdul Azis misalnya, dalam masa kekhalifahannya yang singkat bisa meredus kemiskinan bahkan mengentaskan kemiskinan.

\section{KESIMPULAN DAN SARAN Kesimpulan}

Sebagai kesimpulan dalam akhir tulisan ini adalah bahwa peraturan hukum internasional tentang tanggung jawab negara menyangkut keadaan sekitar di mana ada prinsip-prinsip dengan mana negara yang dirugikan itu menjadi berhak untuk mendapat ganti rugi atas kerugian yang dideritanya atau kerugian yang sedang dialaminya. Tanggung jawab negara telah dinyatakan secara otoritati untuk dibatasi hanya pada tanggung jawab negara untuk tindakan-tindakan yang salah menurut hukum internasional. Mengenai ganti rugi yang diperoleh tergantung keadaan kasus yang seudang dialaminya atau besarnya kerugian yang dideritanya. Biasanya negara yang dirugikan akan berusaha untuk mendapatkan pelunasan melalui perundingan diplomatik dan jika hanya martabatnya yang dilukai, suatu permintaan maaf yang resmi dari negara yang bertanggung jawab atau suatu jaminan bahwa hal tersebut tidak akan terulang lagi. Selanjutnya tanggung jawab dan peranan Negara (pemerintah) terhadap kesejahteraan rakyat dalam konsep islam tetap berpedoman dan kembali kepada ajaran dan apa yang ditegaskan dalam Al-Qur'an dan pemerintah harus memberikan yang terbaik untuk kesejahteraan rakyatnya sebagai kebijakan dalam menghindari kemiskinan.

\section{Saran}

Meskipun Tanggung jawab negara telah dinyatakan secara otoritati untuk dibatasi hanya pada tanggung jawab negara untuk tindakan-tindakan yang salah menurut hukum internasional. Mengenai ganti rugi yang diperoleh tergantung keadaan kasus yang seudang dialaminya atau besarnya kerugian yang dideritanya. Kedepannya negara yang dirugikan untuk mendapatkan pelunasan melalui perundingan diplomatik dan jika hanya martabatnya yang dilukai, suatu permintaan maaf yang resmi dari negara yang bertanggung jawab atau suatu jaminan bahwa hal tersebut tidak akan terulang lagi. Selanjutnya tanggung jawab dan peranan Negara (pemerintah) terhadap kesejahteraan rakyat dalam konsep islam tetap berpedoman dan kembali kepada ajaran dan apa yang ditegaskan dalam Al-Qur'an dan pemerintah harus memberikan yang terbaik untuk kesejahteraan rakyatnya sebagai kebijakan dalam menghindari kemiskinan. 
Konsep Tanggung.Jawab...(Halimahtul, Adawiyah) Volume 3 Nomor 1, Januari-Juni 2018, 29-38 DOI: $\underline{\text { https://doi.org/10.30596/dll.v3i1.3147 }}$

\section{DAFTAR PUSTAKA}

Ali, Zainuddin. (1996). Hukum Islam: Pengantar Hukum Islam di Indonesia. Jakarta: Sinar Grafika.

Ali, Zainuddin. (2008). Hukum Ekonomi Syariah. Jakarta: Sinar Grafika.

Boli, M. Sabon. dkk. (1994). Ilmu Negara dan Buku Panduan Mahasiswa. Jakarta: Gramedia Pustaka.

Hassan, Ali. (1995). Mengenal Nabi Muhammad Saw. Bandung: Diponegoro.

Hidayat, Komaruddin. dkk. (2008). Pendidikan Kewarganegaraan (civics education) Demokrasi. dan Masyarakat Madani. Jakarta: ICCE UIN

Husein, Syahruddin. (1998). Pengantar Ilmu Hukum. KSHM: Fakultas Hukum Universitas Sumatera Utara.

J, G. Starke. (1989). Pengantar Hukum Internasional. Jakarta: Aksara Persada Indonesia.

Kansil. (1976). Pengantar Ilmu Hukum dan Tata Hukum Indonesia. Jakarta: PN. Balai Pustaka.

Kusumaatmadja, Muchtar. (1989). Pengantar Hukum Internasional. Bandung: Binacipta.

Lubis, M Solly. (1990). Ilmu Negara. Bandung: Mandar Maja.

Marzuki, Peter Mahmud. (2011). Penelitian Hukum. Jakarta: Kencana Prenada Media Group.

Parthiana, I wayan. (1990). Pengantar Hukum Internasional. Bandung: Mandar Maju.

Perwataatmadja, Karnaen., \& Syafii'I, Antonio. M. 1999. Apa dan Bagaimana bank Islam (seir ekonomi).Yogyakrta: PT. Dana Bakti Prima Yasa

Sanwani, Mohd.dkk. (1992). Hukum Internsional Suatu Pengantar. KSHM: Fakultas Hukum Universitas Sumatera Utara.

Seokanto, Sorejono \& Muji, Sri. 1996. Pengantar Penelitian Hukum. Jakarta: UI Press.

Seokanto, Sorejono \& Muji, Sri. 2003. Penelitian Hukum Normatif Suatu Tinjauan Singkat. Jakarta: Rajawali Pers.

Tasrif, S. (1987). Hukum Internasional Tentang Pengakuan Dalam Teori dan Praktek. Bandung: Abardin. 